\title{
IMPROVING THE ABILITY TO UNDERSTAND READING CONTENTS THROUGH COOPERATIVE TEAM TYPE ASSISTED LEARNING IN CLASS X STUDENTS OF SMA AL-AMIEN BUGIH
}

\author{
Fredy Yunanto \\ English Language Education Study Program, University of Madura \\ Email: Fredyyunanto2@gmail.com
}

\begin{abstract}
:
Team Assisted Individualization learning method is elaboration learning that is proven effective in helping students memorize reading information. The purpose of this study was: to find out student learning activities, student responses, and improve skills in understanding the contents of the. The research method used was observation, questionnaire, and denag test. The type of research was class $\mathrm{X}$ research of Al-Amien Bugih High School students with 20 students. The researcher used the observation method to find out student learning activities, questionnaires to determine student responses, and test methods to find out the skills to understand the contents of the reading. Analysis of the data using descriptive data analysis. From the results of data analysis, it can be concluded that student learning activities have increased from cycle 1 to good category (2.7) to very good category (3.61) in cycle 2, student responses to improvement from cycle 1 are categorized as negative (50.6) to be positive (70.6) in cycle 2 , and reading comprehension skills improved from cycle 1 to less (50) to be sufficient (70) in cycle 2.
\end{abstract}

Keywords: Team Assisted Individualization, Understanding Reading Contents.

\begin{abstract}
Abstrak:
Metode pembelajaran Individual Assisted Individualization adalah pembelajaran elaborasi yang terbukti efektif dalam membantu siswa menghafal informasi membaca. Tujuan dari penelitian ini adalah: untuk mengetahui kegiatan belajar siswa, respon siswa, dan meningkatkan keterampilan dalam memahami isi bacaan. Metode penelitian yang digunakan adalah observasi, angket, dan tes denag. Jenis penelitian adalah penelitian kelas X siswa SMA Al-Amien Bugih dengan 20 siswa. Peneliti menggunakan metode observasi untuk mengetahui kegiatan belajar siswa, angket untuk menentukan respon siswa, dan metode tes untuk mengetahui keterampilan memahami isi bacaan. Analisis data menggunakan analisis data deskriptif. Dari hasil analisis data, dapat disimpulkan bahwa aktivitas belajar siswa mengalami peningkatan dari siklus 1 ke kategori baik $(2,7)$ menjadi kategori sangat baik $(3,61)$ pada siklus 2 , respons siswa terhadap peningkatan dari siklus 1 dikategorikan negatif $(50,6)$.) menjadi positif $(70,6)$ pada siklus 2 , dan keterampilan membaca pemahaman meningkat dari siklus 1 menjadi kurang (50) menjadi cukup (70) pada siklus 2 .
\end{abstract}

Kata kunci: Team Assisted Individualization, Memahami Konten Membaca. 


\section{Preliminary}

Education is a conscious effort and planned control to create a learning atmosphere and learning process so that students actively develop their potential to have spiritual, self, personality, noble intelligence, and skills needed by themselves, society, nation and state ${ }^{1}$.

The education process that is formally held in schools starting from formal education, the most up to tertiary education, is inseparable from learning activities which is one of the main activities with the teacher as the main role holder and as an education actor ${ }^{2}$.

Within the scope of formal education there must be Indonesian subjects. Indonesian subjects are one of the subjects that exist in each school, including at AlAmien Bugih High School. Indonesian language subjects are programs to develop language skills and be positive towards Indonesian. Indonesian language skills for students are the basis for developing themselves in facing various problems now and in the future. Students who are skilled in Indonesian language will easily give birth to thoughts, ideas, and feelings, both verbally and in writing to others

Teaching languages in accordance with the function of national education, namely developing Indonesian citizens, both as individuals and as members of the community, and able to develop language and cultural functions. With regard to this, the function of language in order to achieve the objectives of national education is to develop and improve the abilities, skills, language techniques in relation to their academic intelligence, communication skills, and attitudes needed for national development. Language skills cover four aspects. The four aspects of language skills include: 1 . Listening, 2. Reading, 3. Listening, 4. Writing 3 .

In the development of science and technology must be supported by the ability to use, develop, and mastery of applied science and balanced basic knowledge. One effort to improve basic mastery is to improve language skills.

The scope of Indonesian Language learning at Al-Amien Bugih High School is from the aspect of the ability to understand the contents of the reading, there are still many who do not understand what is read. Seeing the condition of class X of AlAmien Bugih High School shows that in the learning process students' understanding of reading content seems less enthusiastic, their creativity is low, and students are indifferent, because the material and methods of learning that are taught are less attractive. In Indonesian Language subjects at Al-Amien Bugih High School, from 20 students only $20 \%$ or four students achieved KKM which has been determined by the school, namely 70 . Teachers who have an important role in the teaching and learning process are required to apply several methods that commonly used in the world of education, one of which is the Team Assisted Individualization cooperative learning method.

\footnotetext{
${ }^{1}$ Muhibbin Syah, Psikologi Pendidikan (Dengan Pendekatan Baru). (Bandung: PT Remaja Rosdakarya Offset, 2010), 75

${ }^{2}$ Miftahul Huda, Model-model Pengajaran dan Pembelajaran (Isu-isu Metodis), (Yogyakarta: Pustaka Pelajar, 2013), 66

${ }^{3}$ Guntur Hendry Tarigan, Membaca (Sebagai Keterampilan Membaca), (Bandung: Angkasa Bandung, 2006), 134
} 
Based on these problems, the authors feel the need to study and discuss about how teachers are able to provide motivation to students in reading and students are able to understand the contents of a reading. Here the author offers a solution, one of which is by creating attractive conditions and making reading activities a favorite of students to understand the contents of the reading. The researcher offers a Team Assisted Individualization cooperative learning method so that children are able to understand the meaning of the sentence in writing, by understanding the meanings of the sentence it will make it easier for children to understand the contents of the reading.

The researcher collaborated with the classroom teacher to conduct classroom action research on cooperative learning methods in the type of Team Assisted Individualization in learning Indonesian in class X of Al-Amien Bugih High School. The implementation of this strategy aims to improve the conditions of reading and students' understanding of the content of the reading which has so far been considered to be less than optimal ${ }^{4}$.

This method not only divides students into groups, but also divides teaching materials. By using this method it is expected that students can be more skilled at understanding the contents of the reading it faces, because in reading understanding the contents of the reading required is students' understanding of the reading material. In addition, students are also expected to be able to work with other students. Sharing students in groups will make it easier for students to make social adjustments ${ }^{5}$.

Groups can also improve students' ability to look at a problem and situation with various perspectives. With groups students can also learn to solve a problem together based on the nature, character, and social behavior that is different between students and other students. For this reason the researcher raised the issue in the research proposal and gave the title "Improving the Understanding of Reading Content Skills through Team Assisted Individualization Cooperative Learning in Class X Students of Al-Amien Bugih High School.

\section{Research methods}

This study aims to describe the TAI type of cooperative learning to improve the skills of understanding the contents of the reading. This type of research is Classroom Action Research. This research was conducted in the classroom which aims to improve the practice of learning in the classroom so that students can improve process skills and learning outcomes ${ }^{6}$.

\section{Analysis Technique}

Data analysis method is a method used in order to classify data that has been collected with the aim that the data can function in order to solve the problem under investigation?

\footnotetext{
${ }^{4}$ Robert Slavin, Cooperatife Learnig (Teori Riset dan Praktik). (Bandung: Nusa Media, 2009), 182

${ }^{5}$ Margono. Metodologi Research, (Yogyakarta: Andi, 2004), 29

${ }^{6}$ Burhan Bungin, Metode Penelitian Kuantitatif, (Jakarta: Kencana Predana Media Group, 2011), 98

7 Winarno Surakhmad, Pengantar Penelitian Ilmiah. (Bandung: Tarsito,1998), 83
} 


\section{Determination of Research Subjects}

Before the author describes the total population that is the subject of this study, the authors first discuss the notion of population and sample. In determining research subjects, researchers use the terms population and sample. What is meant by population here is "the whole subject object that is in an area and meets certain conditions relating to the research problem, or the whole unit or individual in the scope to be examined". While the sample is "part of the population of ${ }^{8}$

\section{Data Analysis of Observation Results}

Observation is used to find out the management of learning carried out by teachers in the classroom by using the application of Team Assisted Individualization cooperative learning in improving the skills of understanding the contents of the reading.

\section{Questionnaire Data Analysis}

In knowing the students' responses to cooperative learning Team Assisted Individualization type, researchers used a research formula in the form of a percentage calculated by the formula:

$$
\mathrm{Ri}=\underset{\mathrm{n}}{\mathrm{Si}} \times 100 \% \quad \text { (Kurniastutik, 2008:55) }
$$

1. Information:

2. $\mathrm{Ri}=$ Percentage of students who answered "yes"

3. $\mathrm{Si}=$ Many students who say "no"

4. $\mathrm{n}=$ Lots of students

5. Category of Student Response:

6. Student responses are considered positive if the percentage of students' average answer is $60 \%$. While student responses are considered negative if the average percentage of student answers is $<60 \%$.

\section{Test data}

The test is used to determine the increase in the ability to understand the contents of the reading calculated on the convention of the standard value of the minimum reading ability. The formula used is as follows:

Information:

$$
\text { Mean }=\frac{\sum f x}{N}
$$

$\mathrm{M}=$ Mean (average score)

$\sum \mathrm{fx}=$ Number of scores

$\mathrm{N}=$ Number of students

With the category of determining the final value as follows:

Very good $\rightarrow$ 85-100\%

Good $\rightarrow 75-84 \%$

Enough $\rightarrow 60-74 \%$

Less $\rightarrow 0-59 \%$

\footnotetext{
8 Margono, Metodologi Research. (Yogyakarta: Andi, 2004), 76
} 


\section{Discussion}

To find out the results of applying Team Assisted Individualization learning strategies to improve the ability to understand the reading content of class X ALAmien Bugih High School students, an analysis of the data obtained in cycle 1 and cycle 2 is needed, namely analysis of student activity observation data, analysis data on student response questionnaires, and analysis of test results data. There is an analysis of the data as follows:

\section{Cycle 1 Data Analysis}

Student Activity Observation Results

Student activities in learning during the implementation of the Team Assisted Individualization learning strategy take place in class X of AL-Amien Bugih High School with an observation guide for student activities as attached.

From the final value of each aspect mentioned above, it can be seen that the average final score of the 7 aspects observed in cycle 1 is:

$2.9+2.8+2.8+2.8+3+2+2.9=19.2$.

$\mathrm{NA}=\left(\sum \mathrm{n}\right) /\left(\sum \mathrm{a}\right)=19.2 / 7=2.7$. By referring to the category of determining the final value presented in chapter III with the category of determining the final value as follows:

$$
\begin{aligned}
& 0.00-1.49=\text { less } \\
& 1.50-2.49=\text { enough } \\
& 2.50-3.49=\text { good } \\
& 3.50-4.00=\text { very good }
\end{aligned}
$$

Then the final value obtained for student activity observation in this study is in the good category. This shows that learning activities in the application of Team Assisted Individualization learning strategies to improve the ability to understand the contents of class X of AL-Amien Bugih High School are good.

The results of student activities continue to carry out further activities in an effort to further enhance students' understanding in the application of Team Assisted Individualization learning strategies. The research was continued because the activities of students in daily learning activities were certainly not the same. Therefore, further research is very important to do in accordance with the planning prepared by the researcher.

\section{Repson Student Questionnaire Results}

To analyze the data of the results of student responses to the Team Assisted Individualization learning strategy planning in improving the ability to understand the reading content of class $\mathrm{X}$ students of AL-Amien Bugih High School. So researchers use formulas according to those listed in chapter III, namely $\mathrm{R}=\mathrm{Si} / \mathrm{n}$ $\mathrm{x} 100 \%$.

Based on the results of the questionnaire analysis of student responses in the application of Team Assisted Individualization learning strategies, it can be said that the percentage of students who stated "yes" was $50.6 \%$. While the percentage of students who stated "no" was $44.8 \%$. Because the percentage of students who stated "yes" $\leq 60 \%$, thus the results of students' questionnaire responses to the 
implementation of Team Assisted Individualization learning strategies included the poor category.

\section{Student Test Results}

Student learning outcomes data are obtained after students take part in learning by applying Team Assisted Individualization learning strategies to improve skills in understanding the contents of the reading. the average value of the skills to understand the contents of the reading is 50 . Based on the criteria, then the category is not good.

\section{Reflection}

The process of implementing the Team Assisted Individualization learning strategy in cycle 1 obtained the data presentation of each student activity as follows: 1. In the observation activities about the activities of students who have experienced learning changes as mentioned above, referring to the category of determining the final value presented in the analysis of observation data, student activities can be categorized as good. However, the determination of assessment is the initial view of student activities while in learning activities every day is certainly not the same. Therefore, further action is needed to provide students with understanding in Team Assisted Individualization learning.

2. Based on the recapitulation of questionnaires on students' responses to the implementation of Team Assisted Individualization learning strategies, it can be said that students do not understand the Team Assisted Individualization learning strategy so that questionnaires need to be held again to find out how far students respond to these activities.

3. The results of the tests conducted in cycle 1 show less than optimal results. So it is necessary to give different tests to test students' abilities.

So it can be concluded that the results of the research on the first cycle have so many shortcomings that research needs to be conducted again in cycle 2 . The deficiencies that occur in the first cycle are as follows: a) the language used is difficult to understand (not communicative), b) lazy to read and, c) lack of digestion or understanding of the meaning being read.

\section{Cycle 2 Data Analysis}

\section{Results of Student Activity Observations}

Observation of student activities during the application of Team Assisted Individualization learning strategies to improve the ability to understand student reading content. From the calculation of the final value of each aspect mentioned above, it can be seen that the average final score of the 7 aspects observed in cycle 2 is:

$$
3,4+3,7+3,7+3,7+3,4+3,7+3,7=25,3
$$

$\mathrm{NA}=\left(\sum \mathrm{n}\right) /\left(\sum \mathrm{a}\right)=25 / 7=3.61$. With reference to the final value determination category. The categories for determining the final value are as follows:

$$
\begin{aligned}
& 0.00-1.49=\text { less } \\
& 1.50-2.49=\text { enough }
\end{aligned}
$$


$2.50-3.49=$ good

$3.50-4.00=$ very good

Then the final value obtained for observing the activities of students in this study included very good categories. This shows that learning activities in the application of Team Assisted Individualization learning strategies to improve the ability to understand the contents of class X of AL-Amien High School Bugihalah are very good.

\section{Repson Student Questionnaire Results}

To analyze data on the results of student responses to the planning of Team Assisted Individualization strategies in improving the ability to understand the reading content of class X students of AL-Amien Bugih High School. So researchers use formulas according to those listed, namely $\mathrm{R}=\mathrm{Si} / \mathrm{n} \times 100 \%$.

The results of student responses, it can be seen that the percentage of students who say "yes" is $70.6 \%$ while the percentage of students who say "no" is $29.3 \%$ because of the percentage of students who say "yes" $\geq 60 \%$. Thus, students' responses to the application of Team Assisted Individualization learning strategies can be categorized as good.

So, it can be concluded that an increase in the response of students who stated "yes" to the application of Team Assisted Individualization learning strategies from cycle 1 to cycle 2 was $20 \%$.

\section{Student Test Results}

In analyzing test results or learning outcomes, the percentage of reading ability can be determined by the following formula:

Mean $=\left(\sum x\right) / N$

Student learning outcomes data are obtained after students take part in learning by applying Team Assisted Individualization learning strategies to improve skills in understanding the contents of the reading. The second test was carried out because in the first cycle the test results obtained by the students were not so good that further tests were needed and it was found that the average skill score for understanding the contents of the reading was 70 . Based on the criteria set out in chapter III, it included sufficient categories.

\section{Reflection}

In the first cycle there were so many shortcomings that many students reached below average and were not suitable which were expected by researchers caused by several factors, namely as follows: a) the language used was difficult to understand (not communicative), b) lazy to read and, c) lack of digestion or understanding of the meaning being read. So that in the first cycle there should be a research again, namely in cycle 2 . In this second cycle the researcher conducts research again such as carrying out reconsideration, distributing questionnaires and giving a retest before the teacher repeats material such as cycle 1 but the teacher really cares for students who might not understand the material that was delivered. In this second cycle the teacher really seeks to cover up weaknesses or 
shortcomings that previously occurred by way of the teacher helping students in the KBM process if necessary.

In the second cycle, it turns out that from cycle 1 to cycle 2 there is an increase so that the final value or the results obtained reach the KKM that has been determined and is quite satisfying.

\section{Conclusion}

Based on the results of the research conducted in the field and the results of data analysis in chapter V, a conclusion can be drawn as follows: (1) Student learning activities with the application of Team Assisted Individualization learning strategies to improve skills in reading content in class X Al-Amien High School Bugih $2018 / 2019$ school year has increased from cycle 1 with good category (2.7) to very good (3.61) in cycle 2. (2) Student responses to the application of Team Assisted Individualization learning strategies to improve skills in understanding the contents of the reading in class X Al-Amien Bugih High School 2018/2019 academic year experienced an increase from cycle 1 with a negative category (50.6\%) to positive $(70.6 \%)$ in cycle 2. (3) Skills to understand the contents of the reading through the implementation of Team learning strategies Assisted Individualization in class X of Al-Amien Bugih High School 2018/2019 has increased from cycle 1 with less category (50) men so enough (70) in cycle 2.

\section{Bibliography}

Bungin, Burhan. Metode Penelitian Kuantitatif, (Jakarta: Kencana Predana Media Group, 2011)

Huda, Miftahul. Model-model Pengajaran dan Pembelajaran (Isu-isu Metodis), (Yogyakarta: Pustaka Pelajar, 2013)

Margono, Metodologi Research. (Yogyakarta: Andi, 2004)

Margono. Metodologi Research, (Yogyakarta: Andi, 2004)

Slavin, Robert. Cooperatife Learnig (Teori Riset dan Praktik). (Bandung: Nusa Media, 2009)

Surakhmad, Winarno. Pengantar Penelitian Ilmiah. (Bandung: Tarsito,1998)

Syah, Muhibbin. Psikologi Pendidikan (Dengan Pendekatan Baru). (Bandung: PT Remaja Rosdakarya Offset, 2010)

Tarigan, Guntur Hendry. Membaca (Sebagai Keterampilan Membaca), (Bandung: Angkasa Bandung, 2006) 